\title{
IMPROVING SORGHUM BIOMASS AND Productivity THROUGH APPLiCATION OF MORINGA LEAF JUICE
}

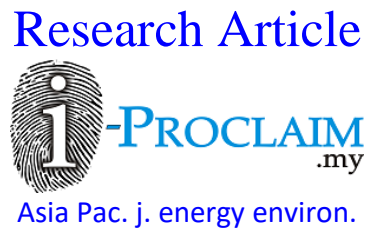

\section{Abrham Tezera Gessesse*, Hailie Shiferaw, Tesfaye T/Haymanot, Mesafint Minale, Abeje Tedila, Getabalew Teshome, Melese Bekele, Reta Eshet}

Amhara Agricultural Research Institute (ARARI), Debre Birhan Agricultural Research Center, Debre Birhan, P.O. Box, 112, ETHIOPIA

*Email for Correspondence: abrhamtezera@gmail.com

Abstract

Globally, fourteen types of Moringa species are discovered. Among these species Moringaoleifera and Moringastenopetala potentially use for nutritional purpose, medicinal and feed values. In addition to these, Moringa leaf juice is being use in the form of a foliar spray that causes the plants to be stronger, more resistant to pests and disease and enhances plant growth. Plants treated with Moringa juice spray produce more and larger fruit and consequently have higher yield. The study conducted at "Kewet" district, Shewa Robit site with the objective of evaluating the contribution of Moringa leaf juice on grain yield and biomass production of sorghum. The result indicated that there was no significant difference observed among treatments on grain yield. However, foliar spray of Moringaoleifera with fertilizer and Moringastenopetala with fertilizer was obtained $25 \%$ and $34 \%$ of grain yield advantage as compare to only chemical fertilization application. Hence, at Shewarobit condition, foliar spray of Moringa leaf juice is not recommended for sorghum grain yield production. However further study is required across different soil type and agro climatology.

Key words

Moringaoleifera, Moringastenopetala, Sorghum, Grain Yield

This article is is licensed under a Creative Commons Attribution-NonCommercial 4.0 International License.

Attribution-NonCommercial (CC BY-NC) license lets others remix, tweak, and build upon work non-commercially, and although the new works must also acknowledge \& be non-commercial.

\section{INTRODUCTION}

Moringa tree or plant belongs to the family Moringaceae. The family consists of a single genus with about fourteen species (Verdcourt, 2000). Among these, the best studied in regarding different purposes is Moringastenopetala and Moringaoleifera. These species are the most domesticated of the genus (Yalemtsehay Mekonnen, 2003). Moringastenopetala is endemic to East Africa and mainly present in northern Kenya and Ethiopia. This native species is the second most important regarding to domestication but has a higher genetic base than Moringaoleifera. According to the Flora of Ethiopia, the species occurs in Kaffa, Gamo-Gofa and Sidama, between 500 and 1600 m.a.s.l and in conditions extend to 2000 m.a.s.l (Edwards et al., 1996). Moringaoleifera is an important food commodity that has had enormous attention as the natural nutrition of the tropics. The leaves, fruit, flowers and immature pods of Moringa trees/plants are used as a highly nutritive vegetable in many countries, particularly in India, Pakistan, Philippines, Hawaii and many parts of Africa (Dsouza and Kulkarni, 1993; Anwar and Bhanger, 2003; Anwar et al., 2005).

In addition the above-mentioned purposes, Moringa leaf juice extract with $80 \%$ ethanol contains growth enhancing hormones. The extracted juices used as in the form of a foliar spray; accelerate the growth of young plants. Plants treated by Moringa growth hormone produce more and larger fruit and consequently, increases yield by $25-30 \%$ many crops such as onions, bell pepper, soya, maize, sorghum, coffee, tea, chili, and melon. Research findings indicated that application of Moringa leaf juice on maize crop increased the yields from 60 to 130 quintal per hectare (Foidl et al., 2001). Hence, this research was conducted to evaluate the effect of Moringa leaf juice application on sorghum biomass and grain yield production at Shewa robit condition.

\section{Objectives}

To test the contribution of Moringa leaf juice on grain yield and biomass production of sorghum crop. 


\section{Materials AND Methods}

\section{Description of the study area}

The study was conducted at Kewet district at Shewa robit which is located at $10^{\circ} 5^{\prime} 32^{\prime \prime} \mathrm{N}$ latitude and $39^{\circ} 54^{\prime} 51^{\prime \prime} \mathrm{E}$ longitude with an elevation of 1259 m.a.s.l. in north Shewa zone, Amhara region (figure1), Ethiopia. The district is about $220 \mathrm{~km}$ north east of Addis Ababa. The mean annual rainfall ranges $868 \mathrm{~mm}$ to $1386 \mathrm{~mm}$ and the mean minimum and seasonal maximum temperature is $14.2^{\circ} \mathrm{C}$ and $30.1^{\circ} \mathrm{C}$ respectively.

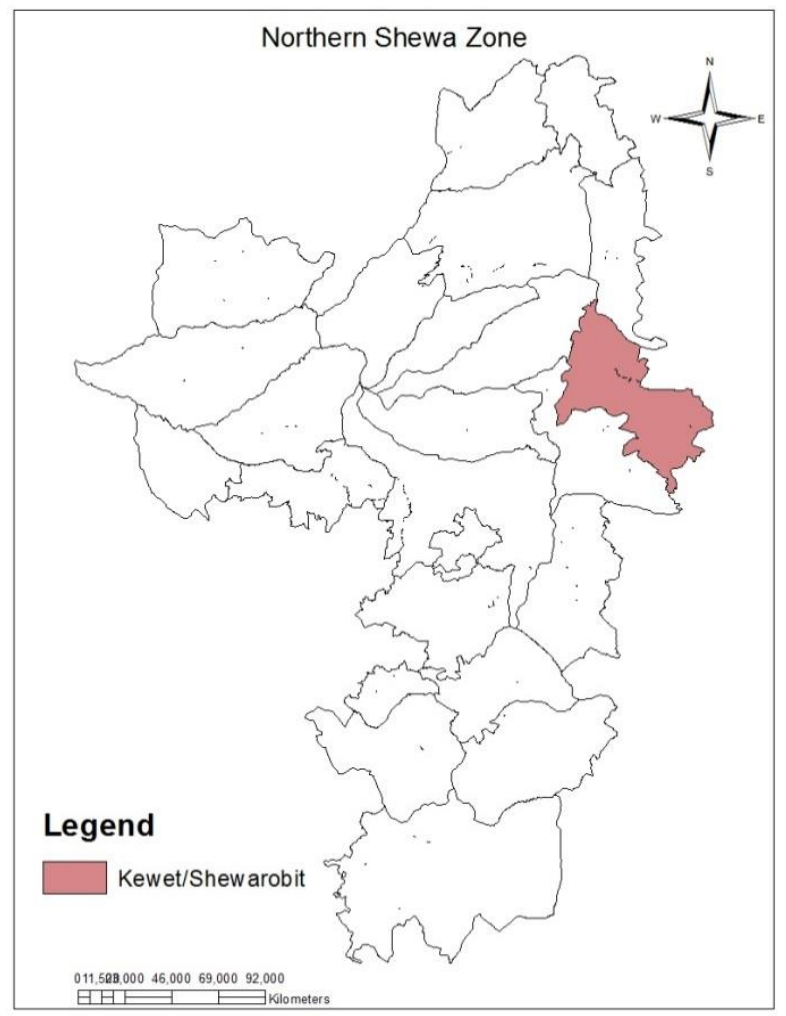

Figure 1: Map of study area

\section{Method of extraction and application of Moringa leaf juice}

Seedlings of Moringaoleifera and Moringastenopetala species grown at Shewarobit nursery site before one and half months of extraction of juice was made. Extraction done by grinding young Moringa leave by mortar together with $80 \%$ ethanol (Martin Price, 2007). Then solid materials were filtered by placing the solution in a white cloth and wringing out the liquid. Finally, dilution of the extracted Moringa juice by water 1:36 ratio and apply 25ml per plant directly on test crops within five hours. The foliar spray applied at three stages; 10 days after the moment plants emerge; plants begin to flower and at maturity stage.

\section{Experimental design and crop management}

The experiment were carried out on sorghum bicolor (Teshale variety) with four treatments (fertilizer with Moringaoleifera juice (MOF), fertilize with Moringastenopetala juice (MSF), Only Moringaoleifera juice (MO), Only Moringastenopetala juice (MS) and Only fertilizer (FO)) as control were used in $3 \mathrm{~m}$ x $5 \mathrm{~m}$ plot size in randomized complete block design with three replication at three experimental sites. The space between blocks and plots were $2 \mathrm{~m}$ and $1 \mathrm{~m}$, respectively and between plants and rows were $15 \mathrm{~cm}$ and $75 \mathrm{~cm}$, respectively. Above ground biomass, plant height, grain yield, numbers of tiller per plant and root biomass were collected and analyzed through SAS statistical package. Significant differences among treatment were tested using Duncan's Multiple Range Test at 0.05 significant levels.

\section{Result AND Discussion}

\section{Effect of Moringa leaf juice on grain yield and plant height}

The result indicated that an application of Moringa leaf juice on sorghum bicolar (Teshal variety) there was no significant difference observed on grain yield in all experimental sites. Although there is not significant variations observed between treatments yet, use of foliar spray of Moringaoleifera juice with fertilizer and Moringastenopetala 
juice with fertilizer to some extent increases sorghum grain yield by $25 \%$ and $34 \%$ over only fertilizer use. This result in line with for many crops such as onions, bell pepper, maize, sorghum, coffee, tea, chili, and melon yields increased by $25-30 \%$ as a result of Moringa leaves juices sprays (Foidl et al., 2001).

Table 1: Effects of Moringa leaf juice on plant height $(\mathrm{cm})$, and grain yield $\left(\mathrm{Ql} \mathrm{ha}{ }^{-1}\right)$ on sorghum bicolar at Shewa robit/Kewet

\begin{tabular}{|c|c|c|c|c|c|c|c|c|c|c|}
\hline \multirow{5}{*}{ Treatments } & \multicolumn{10}{|c|}{ Cropping seasons } \\
\hline & \multicolumn{8}{|c|}{$2011 / 12$} & \multicolumn{2}{|c|}{$2012 / 13$} \\
\hline & \multicolumn{10}{|c|}{ Experimental sites } \\
\hline & \multicolumn{2}{|c|}{ On-station } & \multicolumn{2}{|c|}{ Kobo } & \multicolumn{2}{|c|}{ Wanza } & \multicolumn{2}{|c|}{ average } & \multicolumn{2}{|c|}{ On-station } \\
\hline & GY & $\mathrm{Ht}$ & GY & $\mathrm{Ht}$ & GY & $\mathrm{Ht}$ & GY & $\mathrm{Ht}$ & GY & $\mathrm{Ht}$ \\
\hline MSF & 56.13 & 226 & 35.26 & $215 a$ & 39.08 & 195 & $43.48 \mathrm{a}$ & 212 & $63.7 \mathrm{a}$ & $242.9 a$ \\
\hline MOF & 51.53 & 227 & 31.95 & $208 \mathrm{ab}$ & 38.56 & 194 & $40.69 a$ & 210 & $64.3 \mathrm{a}$ & $243.2 a$ \\
\hline $\mathrm{FO}$ & 43.13 & 248 & 29.07 & $212 a$ & 24.4 & 190 & $32.35 \mathrm{~b}$ & 217 & $63.41 \mathrm{a}$ & $237.5 \mathrm{a}$ \\
\hline $\mathrm{MO}$ & 41.80 & 219 & 27.39 & $193 \mathrm{ab}$ & 23.67 & 182 & $30.95 b$ & 198 & $47.7 \mathrm{~b}$ & $200.6 \mathrm{~b}$ \\
\hline MS & 41.23 & 222 & 28.73 & $181 \mathrm{~b}$ & 24.4 & 189 & $31.45 \mathrm{~b}$ & 197 & $52.44 \mathrm{ab}$ & $226.3 a$ \\
\hline c.v. & 17.00 & 10.36 & 17.95 & 7.48 & 30.04 & 9.83 & 20.8 & 9.02 & 10.1 & 4.8 \\
\hline
\end{tabular}

Columns with the same letters are not significant different.

Where:

MSF (Moringastenopetala with fertilizer), MOF (Moringaoleifera with fertilizer), FO (fertilizer only), MO (Moringaoleifera only) and MS (Moringastenopetala only).

\section{Effect of Moringa leaf juice on plant biomass}

The result indicates that application of Moringa leaf juice with fertilizer on sorghum bicolor above ground biomass and the numbers of tillers per plant was significant variation observed between treatments. But root biomass and number of tiller per plant didn't show significant variation (Table 2). Application of Moringastenopetala leaf juice with fertilizer and Moringaoleifera with fertilizer increases above ground biomass by $7 \%$ and $38 \%$ as compared to only fertilizer application.

Table2. Effect of Moringa leaves juice on sorghum biomass yields in 2012/13 at Shewa robit site.

\begin{tabular}{|l|c|c|c|}
\hline Treatments & above ground biomass $\left(\right.$ ton $\mathrm{ha}^{-1}$ ) & root biomass $(\mathrm{kg})$ per plan & Number of tiller per plant \\
\hline MSF & $13.650 \mathrm{~b}$ & 0.382 & 1.70 \\
\hline MOF & $17.710 \mathrm{a}$ & 0.323 & 1.65 \\
\hline FO & $12.777 \mathrm{bc}$ & 0.317 & 1.60 \\
\hline MO & $9.867 \mathrm{~cd}$ & 0.313 & 1.56 \\
\hline MS & $8.970 \mathrm{~d}$ & 0.273 & 1.50 \\
\hline CV & 14.8 & 22.8 & 5.7 \\
\hline
\end{tabular}

Columns with the same letters are not significant different.

Where:

MSF (Moringastenopetala with fertilizer), MOF (Moringaoleifera with fertilizer), FO (fertilizer only), MO

(Moringaoleifera only) and MS (Moringastenopetala only).

\section{CONCLUSION AND RECOMMENDATION}

Application of Moringa leaf juice on sorghum bicolor has not shown that significant variation in grain yield among treatments while above ground biomass was significantly different. Even if there is no statically significant variation observed, Moringaoleifera and Moringastenopetala leaf juice application on sorghum bicolor offer more than 8 and 11 Quintal per hectare respectively as compare to only fertilizer application. Hence, we can conclude that foliar spray application of Moringa leaf juice for sorghum grain yield production is not recommended at Shewa robit condition. Nevertheless some quintal difference is there, further study needed on cost benefit analysis of application of Moringa leaf juice for sorghum grain yield production.

\section{ACKNOWLEDGEMENT}

This research activity is supported by Amhara Region Agricultural Research Institute (ARARI), Amhara, Ethiopia. 


\section{RefERENCE}

Anwar F, Ashraf M, Bhanger MI. 2005. Inter provenance variation in the composition of Moringa oleifera oilseeds from Pakistan. J Am Oil Chem Soc82: 45-51.

Anwar F, Bhanger MI. 2003. Analytical characterization of Moringa oleifera seed oil grown in temperate regions of Pakistan. J Agric Food Chem 51: 6558-6563

D'souza J, Kulkarni AR. 1993. Comparative studies on nutritive values of tender foliage of seedlings and mature plants of Moringaoleifera Lam. J Econ Taxon Bot 17: 479-485.

Dillard CJ, German JB. 2000. Phytochemicals: nutraceuticals and human health: A review. J Sci Food Agric 80: 1744-1756.

Edwards, D.G.W. and El-Kassaby, Y.A. (1996). The biology and management of forest seeds: genetic perspectives. Forestry Chronicle 72, 481-484.

Foidl, N., Makkar, H.P.S. and Becker, K., 2001. The potential of Moringaoleifera for agricultural and industrial uses, pp 45-76, In: The Miracle Tree: The Multiple Attributes of Moringa (Ed) Lowell J. Fuglie, CTA, Wageningen, The Netherlands

Martin L. Price, 2007. The Moringa Tree. ECHO's Technical note.

Siddhuraju P, Becker K. 2003. Antioxidant properties of various solvent extracts of total phenolic constituents from three different agro-climatic origins of drumstick tree (Moringa oleifera Lam.). J Agric Food Chem 15: 2144-2155

Verdcourt 2000. Moringaceae. In Flora of Ethiopia and Eritrea Volume 2, part 1 Mognoliaceae to Flacourtiaceae pp. 155-162 (Edwards, S., Mesfin Tadesse, Sebsebe Demissew and Hedberg, I. eds). The National Herbarium, Ethiopia.

Yalemtsehay Mekonnen, 2003. The multipurpose Moringa Tree: Ethiopia. Institute of Pathobiology, Addis Ababa University, Addis Ababa, Ethiopia

$$
\text { -- } 0 \text {-- }
$$

